\title{
Et Magazin for Kunstnere og Haandværkere
}

af cand.phil. Michael F. Wagner

Efter Napoleonskrigene stod den polytekniske videnskab foran et stort gennembrud i den europæiske offentlighed. Polyteknikken blev båret frem af indtrykket fra den industrielle revolution i England og gødet med romantikkens begejstring for det videnskabelige fremskridt. I mange hovedstæder begyndte teknisk-videnskabelige bøger og tidsskrifter at udkomme efter 1820. Den polytekniske oplysningsvirksomhed var båret frem af meddelelsen, små og store beretninger om teknologi blev det repræsentative medie for teknikken.

Den polytekniske offentlighed var samtidigt under udvikling i de teknologisk 'avancerede' europæiske hovedstæder London, Paris, Wien, Berlin, München og Prag. I USA var en lignende udvikling på vej. Herhjemme var udgivelsen af et polyteknisk magazin i 1826 og åbningen af den polytechniske Læreanstalt i november 1829 med til at placere København centralt i denne bølge af polytekniske oplysning. Dermed begyndte den teknologiske fremskridtsoptimisme også at vælde frem på dansk grund.

\section{Det danske magazin for håndværkere}

I 1826 indledte den nybagte professor i matematik på kunstakademiet og observator ved Runde Taarn, Georg Frederik Ursin (1797-1851), et stort og meget omfattende arbejde med at udgive, redigere, oversætte og skrive artikler til et dansk polyteknisk tidsskrift. Det udkom først under navnet Magazin for Kunstnere og Haandværkere med 500-600 sider tekst og med talrige illustrationer i form af tegninger og tekniske diagrammer i hver årgang. De sidste seks årgange udkom fra 1836 til 1842 som Nyt Magazin for Kunstnere og Haandværkere. Det danske magazin er enestående, som det første egentlige polytekniske tidsskrift, der udkom herhjemme i denne periode. 
Udgiver og redaktør G.F. Ursin var fra starten særdeles bevidst om tidsskriftets funktion og målgrupper. Tidsskriftet skulle først og fremmest oparbejde og formidle polyteknisk kundskab til et teknisk interesseret publikum. Ursin anså magazinet for mødestedet for alle, som arbejdede med tekniske spørgsmål i det daglige virke. Akademikerne, embedsmænd og videnskabsmænd skulle i fællesskab med kunstnere og håndværkere berige den danske polyteknik. Senere udvidede Ursin sine ambitioner til at magazinet skulle blive et nordisk polyteknisk tidsskrift.

Ideen til at udgive et sådant magazin og det "Udvortes" hentede Ursin fra det engelske Magazin for Kunstnere og Haandværkere, "som stod aabent for Meddelelser fra Kunstnere og Haandværkere" og havde til formål "at udbrede i den arbeidende Klasse nyttige Kundskaber".

Magazinet skulle være et forum for udveksling af informationer mellem 'teknikere' og ikke blot et organ for den tekniske oplysning i sig selv. Ursin ønskede primært at styrke den oplysning, der kom fra neden og var bundet til praktiske

\section{Damprogne paaL iverpool. Veien.}

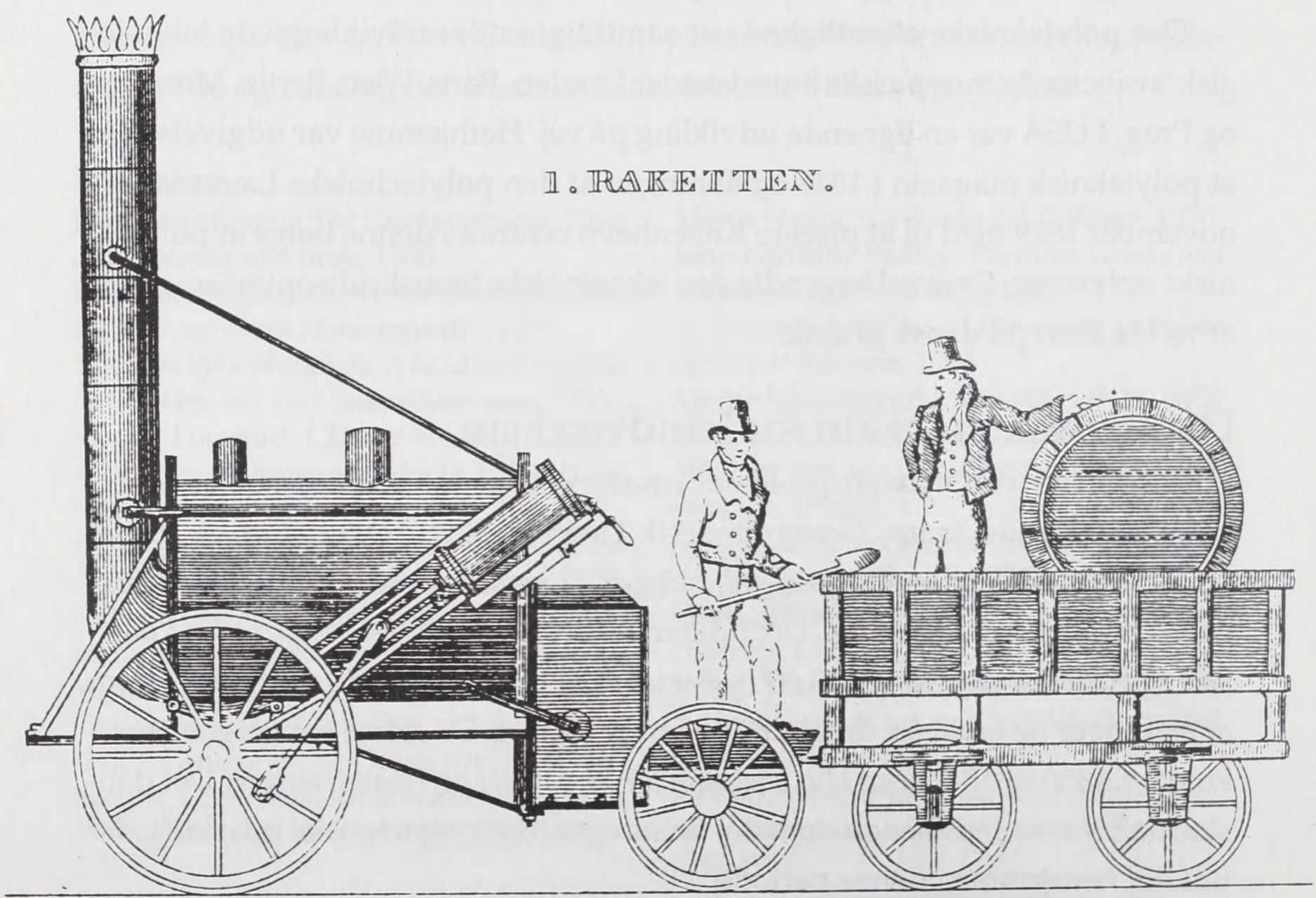


erfaringer, men han bragte også teoretisk videnskabelige meddelelser uden et praktisk sigte, hvis de havde en teoretisk interesse for praktikeren. Følgende tre redaktionelle typer af artikler formidlede den polytekniske kundskab i Magazinet:

Meddelt teknologi i form af beretninger og opskrifter indsendt af læserskaren. Det er artikler, som angiver recepter, fremgangsmåder og metoder til forbedring af eksisterende processer og produkter eller til udvikling af ny teknologi. Mange af de danske meddelelser omhandler mekaniske indretninger eller anvendelse af dampkraften.

En fremtrædende gruppe af originale meddelelser præsenterer de nyeste fremskridt indenfor finmekanikken, typisk instrumentmageri eller urmageriet.

Importerede meddelelser fra andre forlæg, som regel taget fra udenlandske polytekniske tidsskrifter, teknisk-videnskabelige afhandlinger, leksika. Der er altså tale om en teknologioverførsel fra udlandet eller indsamling af informationer om nye metoder, fremgangsmåder, opskrifter og teknikker fra andre kilder. En metode som blev brugt generelt af alle de polytekniske tidsskrifter

Redaktionelt stof $\mathrm{i}$ form af reportager og aktuelle meddelelser fra ind- og udland. En fast rubrik i magazinet var reportagen fra H.C. Ørsteds offentligt tilgængelige månedsforelæsninger, som han var meget nøje med at passe. En anden fast rubrik var den månedlige beretning med udsigt over vejret.

Tegninger fra bd.

5, 1830 .

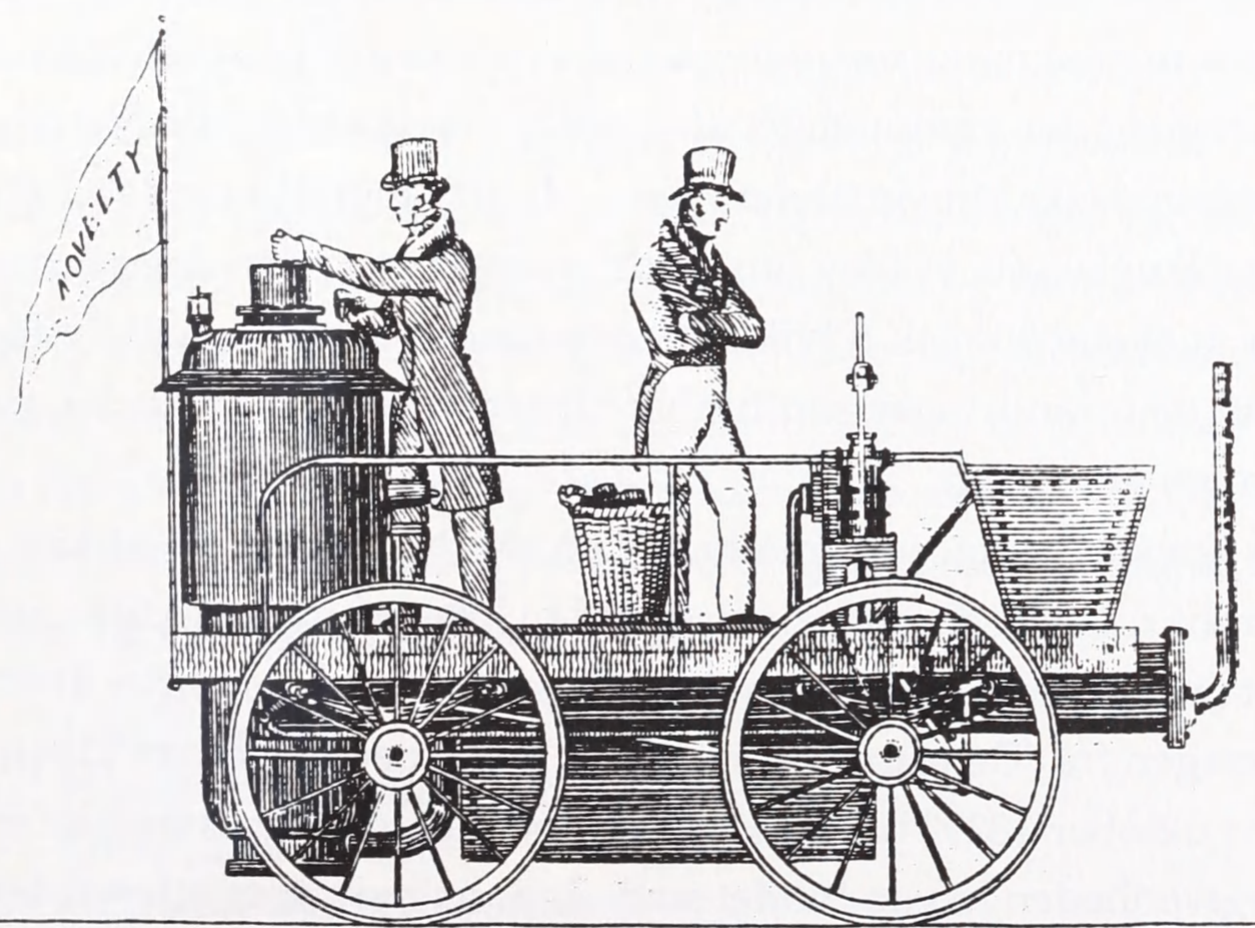




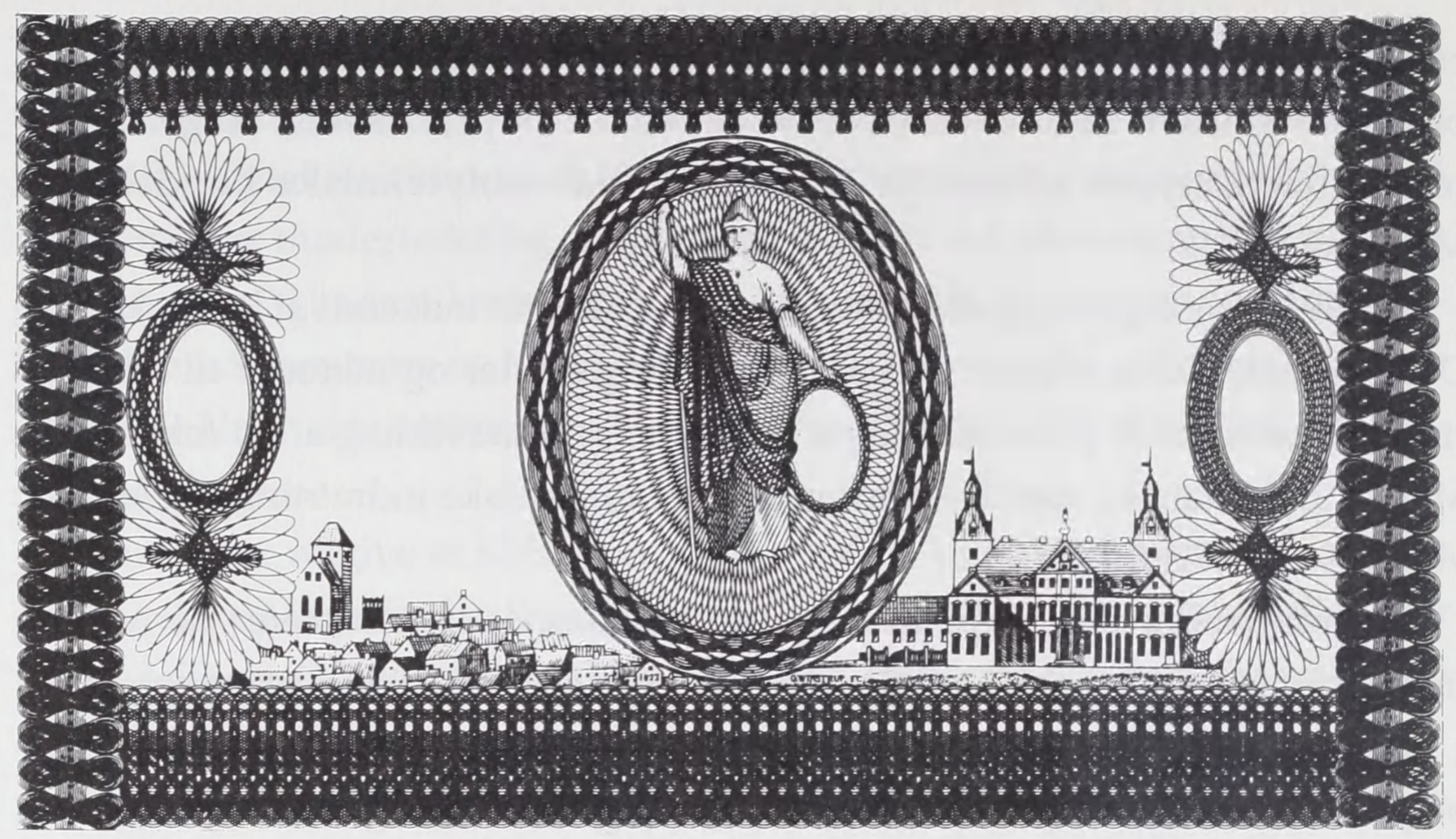

No. 51, 20. aug. 1827: "Om Maskinstikkeri og Staalgravering af O.J. Winstrup, Mechanikus og Dannebrogsmand". Maskinstukken og ueftergørlig pengeseddel.

\section{Nyheden om den ny teknologi}

Det polytekniske tidsskrift måtte i sagens natur være nyhedsorienteret. Det fokuserede stærkt på fremkomsten af nye tekniske opfindelser, forbedring af kendte metoder og alternative processer til at frembringe traditionelle produkter med. Ursin virkede som redaktør velorienteret og var hurtigt fremme med nyheden, hvad enten den stammede fra ind- eller udland.

I faste rubrikker, føljeton-artikler og løbende meddelelser fik læserne god mulighed for at følge med i udviklingen af teknik og samfund. H.C. Ørsted meddelte hver måned friske resultater fra de seneste udførte naturvidenskabelige eksperimenter, der var foretaget af kemikere og fysikere i laboratorier ved forskellige europæiske universiteter. Her optrådte moraliserende indlæg fra læserne. Især laugsvæsenet blev anset for en hæmsko i den frie næring, der skulle til for at skabe teknisk udvikling i samfundet. Her blev også stillet forventninger til de forandringer, samfundsordenen ville blive udsat for gennem oplysningen om teknikken.

Nyheder kræver hastige informationsstrømme. Nyheder og meddelelser fra udlandet kunne nå frem til magazinets spalter i løbet af en månedstid, som det var tilfældet med en lang føljeton om bygningen af en tunnel under Themsen i 1826. Reportagen fra "Den store mekaniske Væddekjørsel mellem Liverpol og Manchester i oktober 1829" havde klar nyhedskarakter. Den fremkom en måned efter begivenheden havde fundet sted. Reportagen var et referat, der byg- 
gede på oversættelsen af de tre foregående udgaver af Londons Mechanic's Magazine, og bragte såvel beskrivelser af hele forløbet som detaljerede tegninger af de tre deltagende lokomotiver. Et tredie eksempel er de tre artikler om "Daguerre's Opfindelse til at frembringe photogeniske Billeder", som blev bragt i august 1839, kort efter Daguerres egen offentliggørelse af artiklen. I oktober og november bragte Magazinet så Daguerre's egen opskrift og beskrivelser af fremgangsmåden ved processen over tre numre.

De indenlandske meddelelser nåede frem så hurtigt som postgangen, sætteriet og trykkeriet tillod det, hvis redaktøren valgte at prioritere 'nyheden' højt. Ursin opdyrkede reportagen i sit tidsskrift, og rejste selv ud som reporter ved flere anledninger. Et godt eksempel var den omfattende reportage magazinet bragte fra indvielsen af Polytechnisk Læreanstalt torsdag den 5. November 1929, den blev bragt i Magazinet allerede fire dage senere.

Modtagelsen ved billedhugger Thorvaldsens hjemkomst i 1838 blev rapporteret i oprømte vendinger ugen efter. Aktuelle politiske kommentarer fandt også indpas i det skjulte. Frederik d. Sjettes dødsfald blev først blev meddelt med sørgerand på forsiden fjorten dage efter, hvad det så end skyldes. Var det tillige en tavs kommentar til den uafklarede politiske situation omkring tronfølgen i 1839 eller måske den rene tilfældighed, at den eneste artikel om udrensning af latriner, der overhovedet på noget tidspunkt optrådte i magazinet, fremkom på samme plads ugen efter, at dødsbudskabet havde været bragt i Magazinet.

\section{Polyteknikkens genstandsfelt}

Polyteknikken anså sig for at være en ny og revolutionerende videnskab til gavn for udviklingen i samfundet. En videnskabelig rationalitetsform, der byggede på naturromantikkens tro på videnskabens historiske fremskridt.

Romantikkens polyteknik var i sin essens en helhedssøgende videnskab, som omhandlede alt i tre sfærer, teknikken, naturlæren og samfundshistorien (sociologien). Polyteknikken kreerede et videnskabeligt genstandsfelt, der i sin holisme såvel som i sine analytiske bestanddele blev sammenfattet i begrebet 'nyttige Kundskaber'. Hvad den nyttige kundskab indebar for Ursin, kan præciseres ved at se på de emnegrupper, som blev systematisk behandlet i magazinet. Det drejer sig om følgende 14 kategorier:

1. Levnedsmidler.

2. Håndværkets redskaber.

3. Energiproduktion.

4. Kemi, metallurgi og optik. 
5. Bygge og anlæg.

6. Transport og infrastruktur.

7. Grafiske fag.

8. Finmekanik.

9. Møbler og husgerråd.

10. Beklædning og konfektion.

11. Mål og vægt, standardisering af normer.

12. Meteorologi.

13. Polyteknikkens tilstand/state of the art.

14. Samfundets indretning og teknikkens betydning.

\section{Den polytekniske offentlighed}

Magazinet havde sin rod i "Selskabet for Naturlærens Udbredelse", som var blevet oprettet i 1824. Herfra fulgte mange af medlemmerne med som subscribenter på magazinet i 1826. Det kan man forvisse sig om ved at sammenligne selskabets første medlemsliste med listen over subscribenter.Ursin oplyste om sin læserskare ved at optrykke en liste over Subscribenter bagest i den første årgang af magazinet. Ved en sammenligning af de to lister fremgår det, at 41 personer går igen på begge lister. Desværre gentog Ursin ikke siden denne liste, så det er ikke muligt at følge udviklingen i denne del af læserskaren gennem årgangene.

Fordelt på erhverv udgjorde de 336 private subscribenter to lige store grupper af personer med fast tilknytning til enten statsapparatet (118) eller den private næring i håndværk og industri (115). Dertil kom en tredie gruppe af subscribenter, der enten havde en formidlende rolle eller ikke havde angivet nogen titel:

Private Subscribenter af Magazin for Kunstnere og Haandværkere I. Årgang, I827.

$\begin{array}{lr}\text { Embedsmænd } & 44 \\ \text { Akademikere } & 26 \\ \text { Aristokrater og Officerer } & 48 \\ \text { Håndværksmestre } & 98 \\ \text { Fabrikanter og Industrialister } & 17 \\ \text { Boghandlere } & 19 \\ \text { Biblioteker } & 5 \\ \text { Studerende } & 2 \\ \text { Skolelærere } & 6 \\ \text { Uden titel } & 61 \\ & \\ \text { I alt } & 336\end{array}$


N: 166.

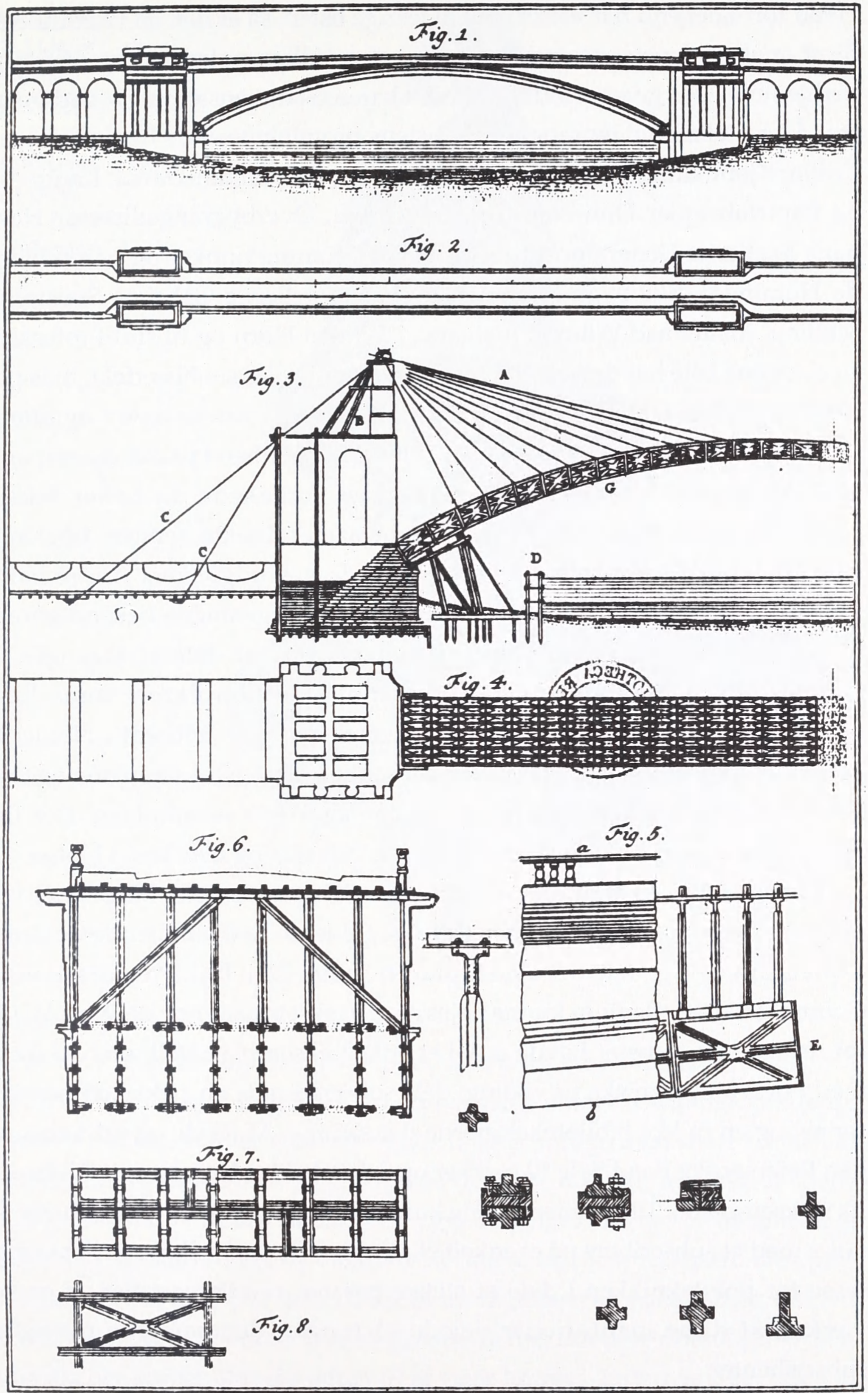

30. marts 1830, No. 155. Seaward's jernstøbte Bro. Nummeret indeholdt iøvrigt artikler om Forfærdigelsen af Bronche=Medailler og Middel mod tør Raaddenskab. 
Hvad formålet end har været med at bringe listen, så er den en værdifuld kilde til at analysere personsammenhænge i den tidlige polytekniske offentlighed herhjemme. Den giver et indbliki læserskarens sammensætning set ud fra navn, stand og titel med dekorationer. Af listens prominente ende fremgår Etatsraad Collin, Kjøbmand i Bourdeaux P. de Coninck, Dr. Nathan-David, Kammerraad og Papirfabriquer Drewsen, Conferentsraad, Overbygningsdirectør Hansen, hans Exellence Generalpostdirectør Hauch, Kammerjunker og Baron Dircinck de Holmfeldt, Skibbygmester Larsen, hans Exellence Gehejme Statsminister Malling, Justitsraad Wiborg, Justitsraad Winkel-Horn og til slut Professor Ørsted. Denne liste havde nok en vis reklameværdi eller snobbeeffekt, hvis potentielle subscribenter skulle lade sig overtale ved at se listens navne og titler.

En optælling af listen viser, at der $i$ alt var subscriberet på 624 eksemplarer af 1827-årgangen. Interessen for magazinet standsede da heller ikke ved subscribenterne. Mange læsere købte magazinet direkte gennem boghandlen eller bestilte de enkelte numre efterfølgende hos udgiveren. Andre har læst Magazinet på et bibliotek eller et selskab. Ursins gentagne bekendtgørelser i magazinets årgange annoncerer disse genoptryk af dele af årgangen. Den Gyldendalske Boghandling aftog alene 50 eksemplarer, mens Reitzel subscriberede på 60 eksemplarer. Magazinet var også udbredt i Norge, hvor Messel, Keyser \& Comp. i Christiania subscriberede på 50 eksemplarer og Preuss, boghandler i Christiansand, havde tegnet sig for 10 eksemplarer. Der findes også andre tegn på, at Magazinet både var udbredt og blev læst i Norge.

Flere statslige institutioner og private selskaber støttede Magazinet ved at aftage et større antal eksemplarer. Det Kgl. General-Toldkammer og CommerceCollegium aftog hele 15 eksemplarer, mens Det Kgl. Admiralitæts- og Commisariats-Collegium kunne nøjes med to eksemplarer og det Kgl. Akademi for de skjønne Kunster havde nok i et enkelt eksemplar. Militæret fulgte også med i den polytekniske udvikling, dels subscriberede en række officerer hver for sig og en række biblioteker gjorde det samme. Af fonde og selskaber aftog den Reiersenske Fond hele 12 stykker og Selskabet for Naturlærens Udbredelse fik ti eksemplarer. Til sammenligning kunne Det Kgl. Landhuusholdningsselskab nøjes med at subscribere på et enkelt eksemplar. Det må tolkes som en stor interesse for polyteknikken i dele af statsapparatet, militærvæsenet og embedsværket, at disse institutioner vejede så tungt i den samlede mængde af subscribenter. 
5. marts 1827.

No. 27. Udsigt

over Steen-

trykkerkunsten

eller

Lithographien.

"Tegnet med

Kridt paa Steen".

Tyroler Gemse-

jæger.

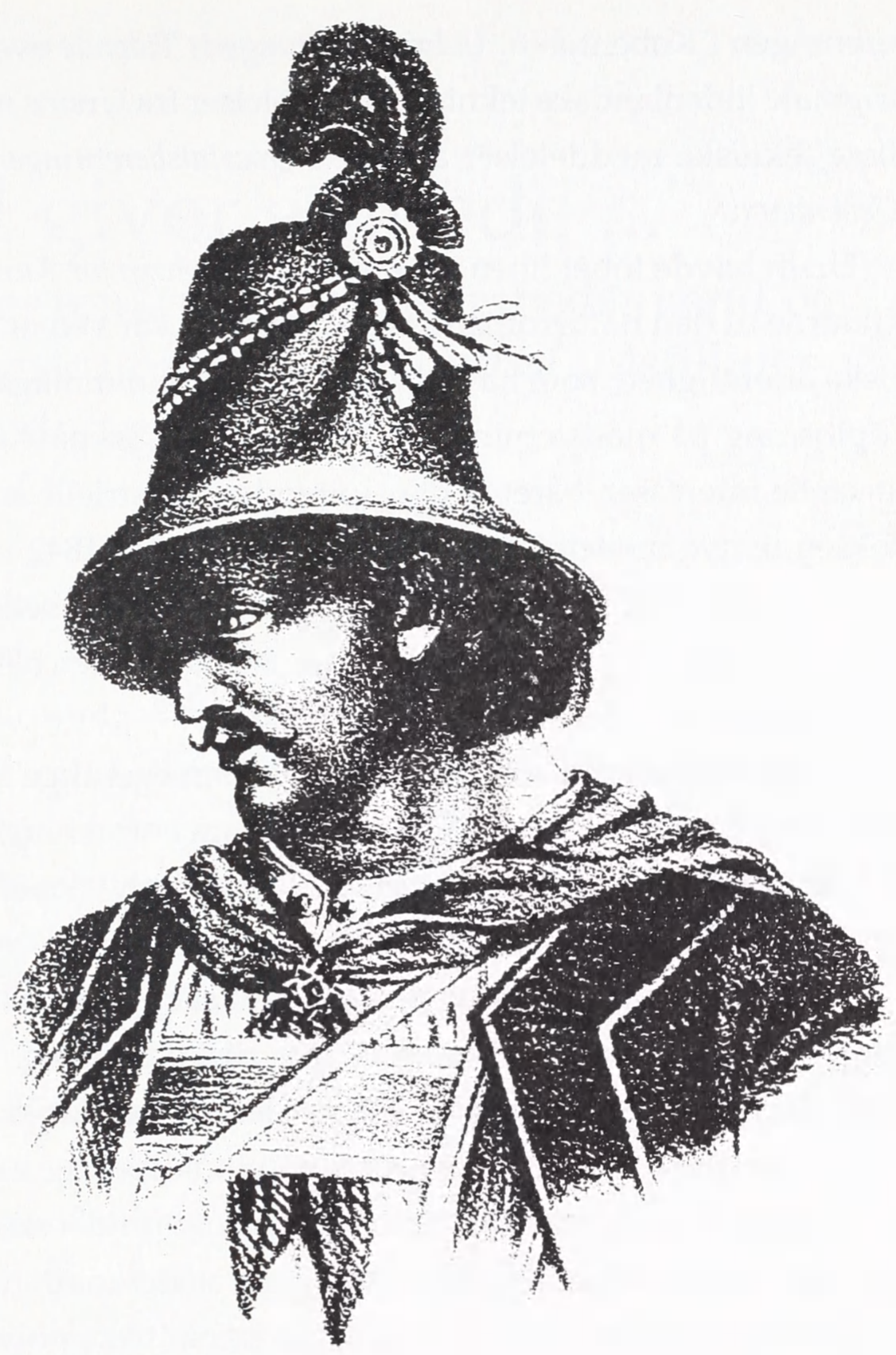

\section{Afslutningen på romantikken}

Magazin for Kunstnere og Haandværkere var et fornemt udtryk for romantikkens polyteknik i dansk udgave. En polyhistorisk anlagt teknologiopfattelse, der hentede sin rationalitet gennem oplysningsfilosofien, men snart kom til at stå i modsætning til behovene og kravene fra det praktiske liv. Teknologiens udvikling i den industrielle produktion byggede i stigende grad på opsplitning, formalisering, specialisering og standardisering af arbejdsprocessen. Den professionelle udvikling af polyteknikken til en ingeniørvidenskab, blev derved løsrevet såvel fra håndværkets teknologi som fra den litterære offentlighed. Naturvidenskaben forbeholdt sig retten til at være herrer $\mathrm{i}$ åndernes rige, uden at interessere sig for en teknologisk praksis. Mekanikusser, industrialister og de få praksis-orienterede polyteknikere fylkedes fra 1838 om den nyoprettede Industri- 
foreningen i København. Industriforeningens Tidende overtog størstedelen af de originale indenlandske tekniske meddelelser fra Ursins magazin. Efter 1839 stod disse tekniske meddelelser at læse i Qvartalsberetninger fra Industriforeningen $i$ Kjøbenhavn.

Ursin havde løbet linen ud med Nyt Magazin for Kunstnere og Haandværkere. Kilderne til den naturromantiske polyteknik var ved at tørre ind. Den polytekniske offentlighed, som havde virket samlet under magazinets virksomhed, gik i opløsning på modsætninger og blev splittet op på varetagelsen af en række specielle interesser, båret af den spirende industrielle kapitalisme og det fremvoksende nye mellemlag af polyteknikere. Efter 1842 var polyteknikken udelukkende knyttet til uddannelsen på den videnskabelige Læreanstalt som en akademisk og teoretisk videnskab. Mens teknologien blev et anliggende for den industrielle produktion.

Ursins polytekniske magazin fik først sin egentlige arvtager i 1890, da Ugebladet Ingeniøren begyndte at udkomme som et foreningsblad for polyteknikerstanden i Danmark. Her blev romantikkens polytekniske genstandsfelt rekonstrueret med saglige tekniske meddelelser af samme type, som havde optaget magazinet. Der blev meddelt nye opfindelser og naturvidenskabelige landvindinger på teknikkens område, lige som diskussionen af samfundsspørgsmålet optog sin del af stofmængden. Forskellen til romantikkens polyteknik lå i det moderne gennembrud og den professionalisering af polyteknikken til en ingeniørvidenskab, som i mellemtiden havde fundet sted. Det betød de facto et monopol på den teknologiske udvikling, i stedet for den udbredelse af polyteknikken til alle klasser i samfundet, den romantiske polyteknik havde bestræbt sig på i ord og gerning.

Artiklen bygger på et foredrag på Det kongelige Biblioteks Bogseminar, 18. maj 1994: Bogen i Danmark 1800-1850. 